\title{
Admissibility of evidence and international criminal justice
}

\section{Admissibilidade da prova e justiça criminal internacional}

\author{
Bartłomiej Krzan ${ }^{1}$ \\ University of Wrocław, Poland \\ bartlomiej.krzan@uwr.edu.pl \\ https://orcid.org/0000-0003-3964-114X
}

ABSTRACT: International criminal procedure combines elements of accusatorial and inquisitorial legal traditions, thus constituting a unique amalgam. Because of the broader scale and the complexity of international criminality to be addressed by international criminal courts and tribunals, it may seem interesting to look at developments and their hitherto experience through the lens of the admissibility of evidence. The presented paper scrutinizes the respective law and practice of the International Military Tribunals, the International Criminal Tribunals for the former Yugoslavia and for Rwanda, and the International Criminal Court, and also makes some general observations on the admissibility of evidence from the perspective of international judiciary as a whole, i.e. not only confined to international judicial bodies of a criminal character. KEYWORDS: admissibility of evidence; international criminal courts and tribunals; international judiciary.

Resumo: O processo penal internacional combina elementos das tradições acusatórias e inquisitórias, assim constituindo um paradigma único. Em razão da escala mais ampla e da maior complexidade da criminalidade internacional a ser enfrentada pelos Tribunais criminais internacionais, pode ser interessante observar os seus desenvolvimentos e históricos diante da temática da admissibilidade probatória. Neste artigo pretende-se analisar a legislação e a prática dos Tribunais Internacionais Militares, os Tribunais Penais Internacionais para

1 University Professor, Department of International and European Law, Faculty of Law, Administration and Economics, University of Wroclaw, Poland. PhD in Law. 
a antiga lugoslávia e para Ruanda, e o Tribunal Penal Internacional, além de apontar comentários gerais sobre admissibilidade da prova em uma perspectiva internacional ampla, ou seja, não somente limitada a órgãos judiciais internacionais de caráter penal.

Palavras-chave: admissibilidade da prova; tribunais penais internacionais; justiça internacional.

\section{INTRODUCTION}

Evidence may be described "as a tool for the reconstruction of disputed past events in the context of judicial trials"2. The term admissibility is "distinctly Anglo-American in origin, and has a technical significance not applicable to the broad rules of international procedure" ${ }^{3}$ Of course, admissibility may have different meanings in different criminal justice systems. Whereas in common law systems the respective scope of potential understandings is much broader, including issues of relevance and the probative value of the information, in civil law inadmissibility would normally be related with improperly obtained evidence ${ }^{4}$. When in a common law criminal trial a judge is to filter the available information that may be offered to a jury, by deciding on its admissibility, the counterpart role of a professional judge in civil law systems is to try the facts. This is yet just one reflection of indeed the different roles assigned for judges, prosecutors, and even defendants in accusatorial and inquisitorial systems.

The present analysis attempts at examining the respective developments concerning the admissibility of evidence in international criminal justice. Unsurprisingly, the combination of the two distinct

2 MURPHY, Peter. Evidence, Proof, and Facts - A Book of Sources. Oxford: OUP, 2003, p. 1.

3 SANDIFER, Durward V. Evidence Before International Tribunals. Chicago: The Foundation Press, 1939, p. 120.

4 SWART, Bert. International criminal courts and the admissibility of evidence. In: THAKUR, R. Chandra; MALCONTENT, Peter (eds.). From Sovereign Impunity to International Accountability: The Search for Justice in a World of States. Tokyo: United Nations University Press, 2004, p. 136. 
procedural systems, and the underlying differences in terms of approaching evidence is worth analyzing, especially against the background of the relevant practice by the international criminal judiciary. It is to address international criminality with a complexity not comparable to ordinary crimes $^{5}$. Hence, in any respect the scale of offences to be prosecuted, as well as the quantity of potential evidentiary sources, affect the operation of proceedings, thus making them incomparable to any domestic criminal proceedings ${ }^{6}$. For that reason our analysis starts with looking at the normative frameworks and their application by International Military Tribunals, the ad hoc Tribunals established by the Security Council, namely the International Criminal Tribunal for the former Yugoslavia (ICTY) and the International Criminal Tribunal for Rwanda (ICTR), and finally by the permanent International Criminal Court (ICC). Subsequently, the troubling combination of adversarial and inquisitorial elements is assessed against the background of proceedings before them. Yet, any reliable examination would be incomplete without then paying attention to the general approach to evidence by international courts, also those of a non-criminal character. It may be claimed that only after taking all those considerations into account, an accurate picture on the admissibility of evidence before international criminal courts and tribunals may be provided.

\section{International Military Tribunals}

The roots of modern international criminal justice date back to the establishment of the International Military Tribunal (IMT) and the International Military Tribunal for the Far East (IMTFE) in the aftermath of the Second World War. The apparently greatest difficulty in establishing the operational framework consisted in how to reconcile

5 DRUMBL, Mark A. Atrocity, Punishment, and International Law, Cambridge: CUP 2007, p. 157.

6 See e.g. OSIEL, Mark. Making Sense of Mass Atrocity, Cambridge: CUP 2009, pp. 106 ff; COGAN, Jacob Katz. The Problem of Obtaining Evidence for International Criminal Courts, Human Rights Quarterly, Vol. 22, no. 2, 2000, pp. $404 \mathrm{ff}$. 
two very different systems of procedure ${ }^{7}$. The statutes of the International Military Tribunals referred only cursorily to evidentiary issues. Article 19 of the IMT Charter provided that: "The Tribunal shall not be bound by technical rules of evidence. It shall adopt and apply to the greatest possible extent expeditious and non-technical procedure, and shall admit any evidence which it deems to be of probative value". Article 13(a) of the IMTFE Charter was framed in a similar manner, with an additional sentence on admissibility of "all purported admissions or statements of the accused". With regard to the proceedings before the latter Tribunal, in his dissenting opinion, Justice Pal levelled severe criticism in the following words: "In prescribing the rules of evidence for this trial the Charter practically discarded all the procedural rules devised by the various national systems of law, based on litigious experience and tradition, to guard a tribunal against erroneous persuasion, and thus left us, in the matter of proof, to guide ourselves independently of any artificial rules of procedure" 8 . There were no specific provisions in the IMT and IMTFE Charters on the exclusion of illegally obtained or improperly obtained evidence.

With regard to International Military Tribunals, it may be therefore questioned whether the malleability of the evidentiary rules provided a potential for abuse, because of their flexibility expanding beyond the bounds of fairness 9 . Some learned commentators, however opined that the relaxation of the rules of evidence did not lead to "any unsatisfactory consequences" and "no question [could] ever be raised concerning the fairness of the rules of evidence and procedure

7 TAYLOR, Telford. The Anatomy of the Nuremberg Trials: A Personal Memoir. London: Bloomsbury 1993, p. 64 referring to Justice Jackson's distraction. Cf. ZAHAR Alexander; SLUITER, Goran. International Criminal Law: A Critical Introduction. Oxford: OUP, 2008, p. 351.

8 Judgment of The Hon'ble Mr. Justice Pal, member from India, $\$ 280$ [reprinted in:] BOISTER, Neil; CRYER, Robert (eds.). Documents on the Tokyo International Military Tribunal: Charter, Indictment and Judgments. Oxford: OUP 2008, p. 932.

9 WALLACH, Evan J. The Procedural and Evidentiary Rules of the Post-World War II Crimes Trials: Did They Provide an Outline for International Legal Procedure. Columbia Journal of Transnational Law Vol. 37, 1999. p. 869. 
administered by the Nuremberg Tribunal" ${ }^{10}$. Be that as it may, for many years the practice of the International Military Tribunals had been the only available reference point in international criminal justice, before the Security Council established the International Criminal Tribunals for the former Yugoslavia and for Rwanda.

\section{THE AD HOC INTERNATIONAL CRIMINAL TRIBUNALS}

Also, the ad hoc international criminal tribunals adopted lenient and flexible admissibility rules on evidence. The Statutes of the ICTY and ICTR conferred on the judges the adoption of "rules of procedure and evidence for the conduct of the pre-trial phase of the proceedings, trials and appeals, the admission of evidence, the protection of victims and witnesses and other appropriate matters"11. The judge-made Rules provided for admission by the Trial Chambers of "any relevant evidence which it deems to have probative value"12. At a later stage, however, the chamber could exclude such evidence ${ }^{13}$. The adopted rules of evidence were considered 'unique' by being "not simply a hybrid of the civil and common law systems" and replicating neither system ${ }^{14}$.

10 GOODHART, Arthur L. The Legality of the Nuremberg Trials. In: METTRAUX, Guénaël. Perspectives on the Nuremberg Trial. Oxford: OUP 2008, pp. 628-629.

11 Art. 15 ICTY Statute, Art. 14 ICTR Statute.

12 Pursuant to respective Rules 89(C) of the ICTY and ICTR Rules of Procedure and Evidence, a Trial Chamber 'may admit any relevant evidence which it deems to have probative value.'

13 ICTY and ICTR Rule 95 states that: 'No evidence shall be admissible if obtained by methods which cast substantial doubt on its reliability or if its admission is antithetical to, and would seriously damage, the integrity of the proceedings.' In addition, ICTY Rule 89(D) provides that: 'A Chamber may exclude evidence if its probative value is substantially outweighed by the need to ensure a fair trial.' The ICTR RPE lacked an analogous rule.

${ }^{14}$ See MACDONALD, Gabrielle Kirk. Trial Procedures and Practices, in MACDONALD, Gabrielle Kirk; SWAAK-GOLDMAN Olivia. Substantive and Procedural Aspects of International Criminal Law: The Experience of International and National Courts. Vol. 1, The Hague: Kluwer Law International, 2000, p. 556. 
In the first annual report of the ICTY, submitted by the President of the Tribunal, Antonio Cassese noted that "[b]ased on the limited precedent of the Nürnberg and Tokyo trials, the statute of the Tribunal has adopted a largely adversarial approach to its procedures, rather than the inquisitorial system prevailing in continental Europe and elsewhere"15. Such an observation was followed by a notice that "there are [...] important deviations from some adversarial systems", mentioning among them the lack of any technical rules for the admissibility of evidence ${ }^{16}$ and that the Tribunal may order the production of additional or new evidence proprio motu ${ }^{17}$. It could be observed that the Tribunal's jurisprudence reflected fully such a statement so that evidence was treated "much more in accordance with the civil law tradition of free proof" despite "paying lip service to the adversarial nature of the Tribunal's proceedings"18.

In the process of establishing the procedural rules for the ICTY, given the limitations arising from the conflict and the conditions in the former Yugoslavia, in particular the restricted possibilities of gaining access to documentary evidence in the process of an ongoing armed conflict,

15 Annual Report of the International Tribunal for the Prosecution of Persons Responsible for Serious Violations of International Humanitarian Law Committed in the Territory of the Former Yugoslavia since 1991, dated 28 July 1994, UN Doc. A/49/342, S/1994/1007, 29 August 1994, § 71.

16 Ibidem, § 72: "The first is that, as at Nürnberg and Tokyo, there are no technical rules for the admissibility of evidence. This Tribunal does not need to shackle itself to restrictive rules that have developed out of the ancient trial-by-jury system. There will be no jury sitting at the Tribunal, needing to be shielded from irrelevancies or given guidance as to the weight of the evidence they have heard. The judges will be solely responsible for weighing the probative value of the evidence before them. Consequently, all relevant evidence may be admitted to the Tribunal unless its probative value is substantially outweighed by the need to ensure a fair trial (rule 89) or where the evidence was obtained by a serious violation of human rights (rule 95).

17 With respect to the latter point, the report continued: "This will enable the Tribunal to ensure that it is fully satisfied with the evidence on which its final decisions are based. It was felt that, in the international sphere, the interests of justice are best served by such a provision and that the diminution, if any, of the parties' rights is minimal by comparison" ( $\$ 73$ ).

18 MURPHY, Peter. Excluding justice or facilitating justice? International criminal law would benefit from rules of evidence. International Journal Evidence and Proof, Vol. 12, 2008, p. 13. 
it was submitted that "the International Tribunal could not be too strict about the criteria for the admissibility of evidence". Accordingly, "it was considered that the inclusion of technical rules would only encumber the judicial process"19. For that reason, the Tribunals' chambers had a broad discretion to decide on the admissibility, relevance, and probative value of evidence ${ }^{20}$. The respective sparseness in formulating of the rules on evidence is deliberate. Rather than it being accidental, the rules are drafted and applied to ensure maximum flexibility for chambers in their efforts to run fair and expeditious trials ${ }^{21}$.

Over time the practice of the ad hoc tribunals moved in the direction of a more active judicial role, despite the textual starting-point being very close to the adversarial model ${ }^{22}$. It was due to the fact that the quite frequent changes were adopted by the judges.

The Appeals Chamber in Aleksovski stated that: "The purpose of the Rules is to promote a fair and expeditious trial, and Trial Chambers must have the flexibility to achieve this goal" ${ }^{\text {"3 }}$. It is quite telling in that

19 ICTY, Trial Chamber, Delalić et al., Decision on the Prosecution's Motion for the Redaction of the Public Record, 5 June 1997, § 41.

20 AMBOS, Kai. International Criminal Procedure: "Adversarial”, "Inquisitorial" or Mixed? In: BOHLANDER Michael (ed.). International Criminal Justice: A Critical Analysis of Institutions and Procedures, London: Cameron May, 2007, p. 477. See also ICTY, Prosecutor v. Simić, Case No. IT-95-9-PT, Decision on the Prosecution Motion Under Rule 73 for a Ruling Concerning the Testimony of a Witness, 27 July 1999, § 40: "In general terms, the Rules establish a regime for the admission of evidence which is wide and liberal".

21 BOAS, Gideon; BISCHOFF, James L.; REID Natalie L.; TAYLOR III, B. Don. International Criminal Law Practitioner Library: International Criminal Procedure, Volume 3, Cambridge: CUP 2011, p. 336. BOAS, Gideon. Admissibility of Evidence Under the Rules of Procedure and Evidence of the ICTY: Development of the "Flexibility Principle". In: MAY, Richard et al. (eds.), Essays on ICTY Procedure and Evidence in Honour of Gabrielle Kirk McDonald. Leiden: Brill, 2001, p. 263.

22 See KRESS, Claus. The Procedural Law of the International Criminal Court in Outline: Anatomy of a Unique Compromise. Journal of International Criminal Justice, Vol. 1, 2003, p. 612; MAY, Richard; WIERDA, Marieke. Trends in International Criminal Evidence: Nuremberg, Tokyo, The Hague, and Arusha, Columbia Journal of Transnational Law, Vol. 37, 1999, p. 727

23 Aleksovski, AC, ICTY, Decision on Prosecutor's Appeal on Admissibility of Evidence, 16 February 1999, § 19. 
respect to refer to the early decision by the ICTY rejecting the motion by the Defence to exclude, to rule on the admission of (hearsay) evidence without actually hearing its content and explained that "This procedure, while possibly appropriate if trials before the International Tribunal were conducted before a jury, is not warranted for the trials are conducted by Judges who are able, by virtue of their training and experience, to hear the evidence in the context in which it was obtained and accord it appropriate weight. Thereafter, they may make a determination as to the relevance and the probative value of the evidence" ${ }^{24}$.

The role of reliability in the admissibility decision may be considered controversial. Indeed, the hitherto jurisprudence (of the ICTY and the ICTR) offered incoherent visions as to the reliability of a piece of evidence being either relevant to its admissibility or as a matter to be considered when determining its weight ${ }^{25}$. It is worth stressing that the ICTR did not adopt Rule 89(D) permitting its Trial Chamber to "exclude evidence if its probative value is substantially outweighed by the need to ensure a fair trial". However, for both ad hoc Tribunals their RPEs offered also mandatory exclusion of evidence if "its admission was antithetical to, and would seriously damage, the integrity of the proceedings" or if it had been obtained by methods which cast substantial doubt on the reliability of the evidence ${ }^{26}$.

\section{The International Criminal Court}

A compromise between the common and civil law tradition needed to be also reached in negotiating the Statute of the permanent

24 ICTY, Prosecutor v. Tadić, Case No. IT-94-1-T, Decision on Defence Motion on Hearsay, 5 August 1996, § 17.

25 COMBS, Nancy. Evidence. In: SCHABAS, William A.; BERNAZ, Nadia (eds.). Routledge Handbook of International Criminal Law. New York: Routledge, 2011, p. 326. Cf. MAY, Richard; WIERDA, Marieke. International Criminal Evidence, Ardsley, NY: Transnational Publishers, 2002, pp. 109-110.

26 See respective rule 95. Since the ICTR Trial Chambers could not rely on a solution similar to that provided in Rule 89(D) of the ICTY RPE they had to rely on Rule 95, whereas the ICTY preferred to make use of Rule 89(D). 
International Criminal Court ${ }^{27}$ resulting in "a delicate combination of civil and common-law concepts of fair trial and due process" 28 . Yet, "the compromise in the Rome Statute was to eschew generally the technical formalities of the common law system of admissibility of evidence in favour of the flexibility of the civil law system, provided that the Court has discretion to "rule on the relevance or admissibility of any evidence" 29 .

When the International Law Commission discussed the establishment of the international criminal court, it was clear to that the rules of evidence were too complex to be dealt with in the Statute itself, and should therefore be left to be defined in a separate document ${ }^{30}$. During subsequent works a decision was taken that the Statute should only contain the fundamental principles governing evidence, and that the details, secondary and subsidiary rules should be further elaborated in the Rules, more easily amended than the Statute ${ }^{31}$ and allowing the Court to flexibly adopt rules according to its practice and requirements ${ }^{32}$. Unsurprisingly, the eventual Rome Statute is not replete with rules of evidence which have been dealt with in full detail in RPE adopted, however, by the Assembly of State Parties ${ }^{33}$.

Yet, Article 69 lays down some general principles serving, in the opinion of some authors, the traditional common-law function of the law

27 FLETCHER, George P. The Interplay of International Criminal Law and Other Bodies of Law, The Influence of the Common Law and Civil Law Traditions on International Criminal Law. In: CASSESE, Antonio (ed.). The Oxford Companion to International Criminal Justice. Oxford: OUP, 2009.

BRADY, Helen. The System of Evidence in the Statute of the International Criminal Court. In: LATTANZI, Flavia; SCHABAS, William A. (eds.). Essays on the Rome Statute of the International Criminal Court. Volume 1, Il Sirente, 1999, p. 286.

29 PIRAGOFF, Donald K.. Evidence. in LEE, R.S. (ed.), The International Criminal Court-Elements of Crimes and Rules of Procedure and Evidence. Ardsley: Transnational Publishers, 2001, pp. 351 and 354. SCHABAS, William A. The International Criminal Court: A Commentary on the Rome Statute, Second Edition. Oxford: OUP, 2016, p. 1079.

31 PIRAGOFF, Donald K.; CLARKE, Paula. Article 69. In: TRIFFTERER, Otto; AMBOS, Kai (eds.). The Rome Statute of the International Criminal Court, Third Edition. Oxford: Hart Publishing, 2016, p. 1722 1996 Preparatory Committee Report I, p. 60.

33 Rome Statute, Article 51. 
of evidence ${ }^{34}$. Again, the provision contains references to different legal traditions and also that of continental law. Under Article 69(3), it is for the parties to submit evidence relevant to the case. However, "[ $t]$ he Court shall have the authority to request the submission of all evidence that it considers necessary for the determination of the truth". The language of the quoted provision might seem to at least partially relate to the inquisitorial model, but not in its most rigid form, since the judges are neither under a strict duty to determine the truth, nor remain passive arbiters to reflect the pure adversarial model ${ }^{35}$.

The most straightforward provision referring to admissibility is Article 69(4): "The Court may rule on the relevance or admissibility of any evidence, taking into account, inter alia, the probative value of the evidence and any prejudice that such evidence may cause to a fair trial or to a fair evaluation of the testimony of a witness". Article 69 belongs to Part 6 concerning the trial proceedings but under Rule 63(1) of the RPE, the rules of evidence, together with Article 69, shall apply in proceedings before all Chambers, thus clarifying the respective ambiguity ${ }^{36}$.

A standard to exclude evidence has been included in Article 69(7) of the Rome Statute. Accordingly, "Evidence obtained by means of a violation of this Statute or internationally recognized human rights shall not be admissible if: (a) The violation casts substantial doubt on the reliability of the evidence; or (b) The admission of the evidence would be antithetical to and would seriously damage the integrity of the proceedings".

It might be rightly questioned whether the above formulation does not 'make a mockery of human rights law as an indivisible set of

34 ORIE, Alphons. Accusatorial versus Inquisitorial Approach in International Criminal Proceedings. In: CASSESE, Antonio; GAETA, Paola; JONES, John R.W.D. (eds.). The Rome Statute of the International Criminal Court: A Commentary. Oxford: OUP, 2002, p. 1485.

35 KRESS, Claus. The Procedural Law of the International Criminal Court in Outline: Anatomy of a Unique Compromise. Journal of International Criminal Justice, Vol. 1, 2003, p. 612.

36 PIRAGOFF, Donald K.. Evidence. In LEE, R.S. (ed.), The International Criminal Court-Elements of Crimes and Rules of Procedure and Evidence. Ardsley: Transnational Publishers, 2001, p. 350. 
minimum legal standards. ${ }^{37}$ Without doubt Article 69(7) provides for a model of non-automatic inadmissibility of illegally obtained evidence ${ }^{38}$. The fairness test would be the ultimate step to finally admit otherwise admissible evidence. The quoted provision focuses on the impact of the violation on the reliability of the evidence and the general integrity of the proceedings ${ }^{39}$.

Finally, the ICC, like its predecessors, is not bound by national rules of evidence ${ }^{40}$. Against this background it may be useful to refer to Prosecutor v. Lubanga, where the Trial Chamber I concluded that "evidence obtained in breach of national procedural laws, even though those rules may implement national standards protecting human rights, does not automatically trigger the application of Article 69(7) of the Statute ${ }^{41}$. The mentioned provision may be considered "lex specialis, when compared with the general admissibility provisions set out elsewhere in the Statute and represents a clear exception to the general approach"42.

The Statute's approach vis-à-vis the admission of evidence is to eschew most of the technical rules on admissibility in favour of a system of utmost flexibility ${ }^{43}$. For some, however, the ICC legal framework does

37 ZAHAR Alexander; SLUITER, Goran. International Criminal Law: A Critical Introduction. Oxford: OUP, 2008, p. 382.

38 JASIŃSKI, Wojciech. Admissibility of Illegally Obtained Evidence in Proceedings before International Criminal Courts. In: KRZAN, Bartłomiej (ed.). Prosecuting International Crimes: A Multidisciplinary Approach. Leiden-Boston: Brill, 2016, p. 217. Cf. FALLAH, Sara Mansour. The Admissibility of Unlawfully Obtained Evidence before International Courts and Tribunals, The Law \& Practice of International Courts and Tribunals, Vol. 19, 2020, p. 148. Cf. Katanga, No. ICC-01/04-01/07-2635, § 39.

40 See e.g. Rome Statute, Art. 69(8): 8. When deciding on the relevance or admissibility of evidence collected by a State, the Court shall not rule on the application of the State's national law"; ICC RPE, Rule 63(5), The Chambers shall not apply national laws governing evidence, other than in accordance with article 21.

41 Prosecutor v. Lubanga, Doc. No. ICC-01/04-01/06-1981, Decision on the Admission of Material from the 'Bar Table', 24 June 2009, § 36 Ibidem, §34. also Lubanga, No. ICC-01/04-01/06-1981, § 34; Katanga, No. ICC-01/04-01/07-2635, § 39 (lex specialis as compared to Art. 69 (4) ICCS).

43 GALLMETZER, Reinhold. The Trial Chamber's Discretionary Power To Devise The Proceedings Before It And Its Exercise In The Trial Of Thomas 
not constitute an improvement, since its law of evidence is "possibly even more obscure than that of the ad hoc tribunals" and contains some utterly contradictory elements ${ }^{44}$. All in all, the general admissibility standard of evidence is defined by three cardinal criteria ${ }^{45}$. Accordingly, relevance, probative value, and prejudice (probative value as weighed against any prejudicial effect on trial fairness) constitute a three-step approach to determine the admissibility of evidence other than oral evidence ${ }^{46}$. First, "the Chamber must ensure that the evidence is prima facie relevant to the trial, in that it relates to the matters that are properly to be considered by the Chamber in its investigation of the charges against the accused and its consideration of the views and concerns of participating victims" ${ }^{47}$. Subsequently, the Chamber must assess whether the evidence has, on a prima facie basis, probative value ${ }^{48}$. Finally, where relevant, the probative

Lubanga Dyilo. In: STAHN, Carsten; SLUITER, Goran (eds.). The Emerging Practice of the International Criminal Court. Leiden: Brill, 2009. p. 507.

ZAHAR Alexander; SLUITER, Goran. International Criminal Law: A Critical Introduction. Oxford: OUP, 2008, p. 394, alluding to the combination of non-compellability of witnesses with a mandatory exclusionary rule for testimonial evidence not subject to cross-examination (rule 68).

GOSNELL, Christopher. Admissibility of Evidence. In: KHAN, Karim A.A.; BUISMAN, Caroline; GOSNELL, Christopher (eds.). Principles of Evidence in International Criminal Justice, Oxford: OUP, 2010, p. 378. As confirmed in other proceedings, the Chamber is to 'first assess the relevance of the material, then determine whether it has probative value and finally weigh its probative value against its potentially prejudicial effect' - see ICC, Trial Chamber II, The Prosecutor v. Germain Katanga and Mathieu Ngudjolo Chui, Decision on the Prosecutor's Bar Table Motions, ICC-01/04-01/07, 17 December 2010, § 14 .

46 ICC, Trial Chamber I, The Prosecutor v. Thomas Lubanga Dyilo, Corrigendum to Decision on the admissibility of four documents, ICC-01/04-01/061399-Corr, 21 January 2011, §§ 25ff.

47 ICC, Trial Chamber I, The Prosecutor v. Thomas Lubanga Dyilo, Corrigendum to Decision on the admissibility of four documents, ICC-01/04-01/061399-Corr, 21 January 2011, § 27.

Ibidem, § 28. Cf. Prosecutor v. Katanga and Ngudjolo, Doc. No. ICC-01/0401/07-717, Decision on the Confirmation of Charges, 30 September 2008, $\S 77$ "According to article 69(4) of the Statute, probative value is one of the factors to be taken into consideration when assessing the admissibility of a piece of evidence. In the view of the Chamber, this means that the Chamber must look at the intrinsic coherence of any item of evidence, and to declare 
value of the evidence must be weighed against its prejudicial effect ${ }^{49}$. Such a three-stage approach may often appear as being very artificial and unnecessarily cumbersome ${ }^{50}$ since it would impose indeed lengthy decisions on admissibility of evidence and as such those would not be indispensable according to the Statute or the Rules.

For the sake of clarity, it may be requested that questions of illegally obtained evidence should be reviewed at the stage of the admission of evidence and not during its assessment ${ }^{51}$. However, the Trial Chamber III decided in Prosecutor $v$. Bemba to admit prima facie before the start of the presentation of evidence, all statements of witnesses to be called to give evidence at trial and all the documents submitted by the prosecution in its list of evidence ${ }^{52}$. According to the Majority of the Judges "a ruling on admissibility is not a pre-condition for the admission of any evidence, as it only implies a prima facie assessment of the relevance of any material, on the basis that it appears to be a priori relevant to the case" ${ }^{53}$.

inadmissible those items of evidence of which probative value is deemed prima facie absent after such an analysis".

49 ICC, Trial Chamber I, The Prosecutor v. Thomas Lubanga Dyilo, Corrigendum to Decision on the admissibility of four documents, ICC-01/04-01/061399-Corr, 21 January 2011, § 29. Observing that: "Whilst it is trite to observe that all evidence that tends to incriminate the accused is also "prejudicial" to him, the Chamber must be careful to ensure that it is not unfair to admit the disputed material, for instance because evidence of slight or minimal probative value has the capacity to prejudice the Chamber's fair assessment of the issues in the case".

50 BITTI, Gilbert. Article 64. In: TRIFFTERER, Otto; AMBOS, Kai (eds.). The Rome Statute of the International Criminal Court, Third Edition. Oxford: Hart Publishing, 2016, p. 1619.

51 JASIŃSKI, Wojciech. Admissibility of Illegally Obtained Evidence in Proceedings before International Criminal Courts. In: KRZAN, Bartłomiej (ed.). Prosecuting International Crimes: A Multidisciplinary Approach. Leiden-Boston: Brill, 2016, p. 202.

52 ICC, Trial Chamber III, The Prosecutor v. Jean-Pierre Bemba Gombo, Decision on the admission into evidence of materials contained in the prosecution's list of evidence, ICC-01/05-01/08-1022, 19 November 2010, §8. Cf Ruto et al. (ICC-01/09-02/11), Decision on the Prosecution's Request for Admission of Documentary Evidence, 10 June 2014, § 15.

53 ICC, Trial Chamber III, The Prosecutor v. Jean-Pierre Bemba Gombo, Decision on the admission into evidence of materials contained in the prosecution's list of evidence, ICC-01/05-01/08-1022, 19 November 2010, § 10. 
The above admission into evidence of all items mentioned on the Revised List of Evidence was based on a "prima facie finding of admissibility", without an item-by-item evaluation or giving reasons was subsequently reversed by the Appeals Chamber. According to the latter, the Trial Chamber has a choice between ruling on the relevance and/or admissibility of each item of evidence when it is submitted or deferring its consideration until the end of the proceedings, thus making it part of its assessment of the evidence when it is evaluating the guilt or innocence of the accused person ${ }^{54}$. The Appeals Chamber underlined that according to the last sentence of Article 74(2) of the Rome Statute a Trial Chamber may base its decision at the end of the trial only on evidence that was "submitted and discussed before it at the trial" 55 . In addition, according to the Appeals Chamber, the Trial Chamber "failed to effectively evaluate any potential prejudice that such evidence may cause to a fair trial, in particular Mr. Bemba's right to a trial without undue delay"56. It has been also suggested in the doctrine ${ }^{57}$ that instead of undertaking an admissibility test at all cost at the moment of submitting pieces of evidence ${ }^{58}$, it may be advisable to defer the Chamber's assessment of the admissibility of evidence until deliberating

54 ICC, Appeals Chamber, The Prosecutor v. Jean-Pierre Bemba Gombo, Judgment on the appeals of Mr. Jean-Pierre Bemba Gombo and the Prosecutor against the decision of Trial Chamber III entitled "Decision on the admission into evidence of materials contained in the prosecution's list of evidence", ICC-01/05-01/08-1386, 03 May 2011, § 37.

55 Ibidem, § 45 .

56 Ibidem, $\$ 70$.

57 AMBOS, Kai. Treatise on International Criminal Law: Volume III: International Criminal Procedure. Oxford: OUP, 2016, p. 449.

58 ICC, Trial Chamber II, The Prosecutor v. Germain Katanga, Decision on the Prosecutor's Bar Table Motions, ICC-01/04-01/07-2635, 19 December $2010, \S 15$ : There are no automatic grounds for exclusion in the Statute or the Rules. Instead, the Chamber has the discretion to weigh the probative value of each particular item of evidence against the potentially prejudicial effect of its admission. This is a balancing test which must be carried out on a case-by-case basis. The Chamber emphasises, however, that, although the applicable admissibility test allows the Chamber wide- discretion, the Chamber has no discretion in whether or not to apply the test. Before admitting any item of evidence, the Chamber must be satisfied that the admissibility criteria have been met. 
its judgment pursuant to Article 74(2) of the Statute ${ }^{59}$. Accordingly, the preliminary admissibility exam would be limited to relevance ${ }^{60}$. Yet, the concept of relevance contains an implicit requirement of probative value. But when compared to the mechanisms available to the ad hoc international criminal tribunals, the respective solution included in the Rome Statute seems too moderate.

One important aspect of the ICC procedure, and also on evidentiary aspects thereof, is that under Rome Statute the Rules of Procedure and Evidence are to be adopted by the Assembly of State Parties and not by judges themselves. Such a mistrust in judges ${ }^{61}$ may also have more serious and definitely negative consequences, including the significant preclusion of the necessary judicial development, while restricting the judges substantially to a mechanical function, which in turn may affect the ability of the International Criminal Court to function efficiently as a court of law and the ability of its judges to fulfil their mandate ${ }^{62}$. Not only against the background of the ICC's predecessors, such a deprivation cannot be considered a welcome development.

59 ICC, Appeals Chamber, The Prosecutor v. Jean-Pierre Bemba Gombo, Judgment on the appeals of Mr. Jean-Pierre Bemba Gombo and the Prosecutor against the decision of Trial Chamber III entitled "Decision on the admission into evidence of materials contained in the prosecution's list of evidence", ICC-01/05-01/08-1386, 03 May 2011, §9: "The Chamber will consider the relevance, probative value and potential prejudice of each item of evidence submitted at that time, though it may not necessarily discuss these aspects for every item submitted in the final judgment".

${ }^{60}$ KLAMBERG, Mark. Evidence in International Criminal Trials. Leiden: Brill, 2013, p. 357. Cf. SCHUON, Christine. The Appeals Decision in the ICC's Jean-Pierre Bemba Gombo Case on the Trial Chamber's 'Decision on the Admission into Evidence of Materials Contained in the Prosecution's List of Evidence'. Leiden Journal of International Law, Vol. 25, 2012, p. 520.

${ }^{61}$ CASSESE, Antonio. The Statute of the International Criminal Court: Some Preliminary Reflections. European Journal of International Law, Vol. 10, 1999, p. 163.

${ }^{62}$ HUNT, David. The International Criminal. Court. High Hopes, 'Creative Ambiguity' and an Unfortunate Mistrust in International Judges. Journal of International Criminal Justice, Vol. 2, 2004, p. 56. 


\section{SquARING INQUISITORIAL LAW OF EVIDENCE IN A Predominantly Adversarial System?}

Without doubt, rules of evidence, when applied consistently, are an essential component of fairness and good trial management ${ }^{63}$. The law and the respective practice of the judicial bodies analysed above offer numerous occasions to draw firm similarities, notwithstanding the differences between the International Military Tribunals, International Criminal Tribunals, and the permanent ICC. Comparing the experiences of those judicial institutions demonstrated various commonalities. Generally speaking, all of the surveyed international judicial bodies have had a flexible and liberal approach to the admission of evidence.

Yet, the "free proof" may be "a euphemism for a systemic failure of judicial discrimination in admitting evidence without inquiring into its apparent provenance or reliability" and "the price of this failure is evidential contamination" ${ }^{64}$.

It goes without saying that international criminal procedure may be portrayed as a competition of or a contest between two conflicting traditions of criminal procedure. In general, it may be concluded that the international criminal procedure is dominated by the common-law adversarial model but the international criminal courts and tribunals have been relying on essentially civil-law mechanisms for tendering and admitting evidence ${ }^{65}$. Thus, international criminal evidence rules constitute a unique amalgam. The trial proceedings are primarily common law in character but basic approach to evidence

63 GOSNELL, Christopher. Admissibility of Evidence. In: KHAN, Karim A.A.; BUISMAN, Caroline; GOSNELL, Christopher (eds.). Principles of Evidence in International Criminal Justice, Oxford: OUP, 2010, p. 442.

64 MURPHY, Peter. No Free Lunch, No Free Proof: The Indiscriminate Admission of Evidence is a Serious Flaw in International Criminal Trials. Journal of International Criminal Justice, Vol. 8, 2010, p. 540.

65 KWON, O-Gon. The Challenge of An International Criminal Trial as Seen from the Bench. Journal of International Criminal Justice, Vol. 5, 2007, pp. 363-364, see also KRESS, Claus. The Procedural Law of the International Criminal Court in Outline: Anatomy of a Unique Compromise. Journal of International Criminal Justice, Vol. 1, 2003, p. 612. 
derives from civil law systems, which when blended together provide for inevitable tensions ${ }^{66}$.

When assessing the international intersection of traditions, it is rightly feared that "the mishmash of the two system has abandoned some distinctive checks on which each system depends" ${ }^{\prime 7}$. In even stronger words it may be observed in a broader context that "the present system of 'free proof' in the context of international criminal law represents a judicial failure to exercise due discretion by indiscriminately admitting any material claimed by the parties to be 'evidence', regardless of its provenance or apparent reliability and even without inquiry as to possible perjury or fabrication” ${ }^{\circ}$.

Against this particular background it may seem natural to advocate for fully choosing either system, for the selected law of evidence "can only function properly in their respective 'natural habitats', which is either the civil-law objective truth-finding contest or the common-law subjective truth finding contest" ${ }^{\circ 9}$.

It is thus logical that the representatives of the common law system level criticism against the missing elements. The "deviations" from the adversarial system are considered to frustrate its objective "by making trials longer, more complex, and less efficient, and by tending to bury the truly important evidence in the midst of an enormous accumulation of evidential debris." ${ }^{\text {. }}$. Such "evidential debris" may be said to poison

66 COMBS, Nancy. Evidence. In: SCHABAS, William A.; BERNAZ, Nadia (eds.). Routledge Handbook of International Criminal Law. New York: Routledge, 2011, p. 329.

67 BIBAS, Stephanos; BURKE-WHITE, William W. International Idealism Meets Domestic-Criminal-Procedure Realism. Duke Law Journal, Vol. 59(4), 2010, p. 695 (at p. 638 complaining that "in blending adversarial and inquisitorial systems, international criminal justice has jettisoned too many safeguards of either one").

68 MURPHY, Peter. No Free Lunch, No Free Proof: The Indiscriminate Admission of Evidence is a Serious Flaw in International Criminal Trials. Journal of International Criminal Justice, Vol. 8, 2010, p. 539.

69 ZAHAR Alexander; SLUITER, Goran. International Criminal Law: A Critical Introduction. Oxford: OUP, 2008, p. 394.

70 MURPHY, Peter. Excluding justice or facilitating justice? International criminal law would benefit from rules of evidence. International Journal Evidence and Proof, Vol. 12, 2008, p. 13. 
the record and ultimately make it more difficult for judges to assess the weight of the evidence and arrive at the truth ${ }^{71}$. In the alternative, it is also possible to argue against any repetition of the reliability assessment, when determining admissibility, and later at the final deliberations. Thus, procedural economy may as well be invoked as an argument in favour of flexible admission of evidence ${ }^{72}$. The latter suggestion may well fit into the international character of the judicial proceedings.

Some reaction to the referred objections is offered in the Separate and Dissenting Opinion of Judge Cassese in Erdemović, which deserves to be quoted at length: "International criminal procedure results from the gradual decanting of national criminal concepts and rules into the international receptacle. [...] It is therefore only natural that international criminal proceedings do not uphold the philosophy behind one of the two national criminal systems to the exclusion of the other; nor do they result from the juxtaposition of elements of the two systems. Rather, they combine and fuse, in a fairly felicitous manner, the adversarial or accusatorial system [...] with a number of significant features of the inquisitorial approach [...]. This combination or amalgamation is unique and begets a legal logic that is qualitatively different from that of each of the two national criminal systems: the philosophy behind international trials is markedly at variance with that underpinning each of those national systems. Also the Statute and Rules of the International Tribunal, in outlining the criminal proceedings before the Trial and Appeals Chambers, do not refer to a specific national criminal approach, but originally take up the accusatorial (or adversarial) system and adapt it to international proceedings, while at the same time upholding some elements of the inquisitorial system"73. In a similar vein, another ICTY President, Gabrielle Kirk MacDonald advocated for the flexibility of procedural and evidentiary

${ }^{71}$ MURPHY, Peter. No Free Lunch, No Free Proof: The Indiscriminate Admission of Evidence is a Serious Flaw in International Criminal Trials. Journal of International Criminal Justice, Vol. 8, 2010, p. 539.

72 KLAMBERG, Mark. Evidence in International Criminal Trials. Leiden: Brill, 2013, p. 419.

73 Erdemovic - Judgement - Separate and Dissenting Opinion of Judge Cassese, Erdemović (IT-96-22), AJ, 7 October 1997, §4. 
rules ("a framework, not a straitjacket") to allow the exercise of judicial discretion where necessary ${ }^{74}$.

Another perspective on the hybridization of the procedure, and the admissibility of evidence in particular, would be the perspective of the fair trial ideal ${ }^{75}$. One might be reminded of the famous reference to the "poisoned chalice" at Nuremberg ${ }^{76}$ that brilliantly covers the delicate interplay between being either too inclined pro-conviction or in the alternative, instead of overlooking rights of the accused to lurch in the opposite direction, with an eagerness to demonstrate unparalleled care for the accused, i.e. being inclined to acquittal at any $\operatorname{cost}^{77}$.

In a more modern fashion, one might be tempted to rely once again on a learned expert of international (criminal) law. According to Cassese (acting then as dissenting Judge in his capacity as the ICTY President in another case), "notions, legal constructs and terms of art upheld in national

74 Remarks made by Judge Gabrielle Kirk McDonald, President of the International Criminal Tribunal for the former Yugoslavia, to the Preparatory Commission for the International Criminal Court, ICTY Press Release JL/P.I.S./425-E (30 July 1999), https://www.icty.org/en/press/ remarks-made-judge-gabrielle-kirk-mcdonald-president-international-criminal-tribunal-former (accessed on 5 December 2020).

75 Such philosophy of the criminal procedure was employed by ICTY in Delalić and others (IT-96-21-T), TC, 4 February 1998, Decision on the Prosecution's Motion for an Order Requiring Advance Disclosure of Witnesses by the Defence, § 20: "The general philosophy of the criminal procedure of the International Tribunal aims at maintaining a balance between the accusatory procedure of the common law systems and the inquisitorial procedure of the civil law systems; whilst at the same time ensuring the doing of justice. [...] both the Statute and the Rules adhere strictly to the elementary principles of justice, and the protection of the essential rights of the accused"

76 On November 21, 1945, in the Palace of Justice at Nuremberg, Germany, Justice Robert H. Jackson, Chief of Counsel for the United States, made his opening statement to the International Military Tribunal and said: "To pass these defendants a poisoned chalice is to put it to our own lips as well. We must summon such detachment and intellectual integrity to our task that this Trial will commend itself to posterity as fulfilling humanity's aspirations to do justice".- see https://www.roberthjackson.org/speech-and-writing/ opening-statement-before-the-international-military-tribunal/ (accessed on 5 December 2020).

77 See: https://www.ejiltalk.org/the-other-poisoned-chalice-unprecedented-evidentiary-standards-in-the-gbagbo-case-part-1/ (accessed on 5 December 2020). 
law should not be automatically applied at the international level. They cannot be mechanically imported into international criminal proceedings. The International Tribunal, being an international body based on the law of nations, must first of all look to the object and purpose of the relevant provisions of its Statute and Rules"78.

This brings to light another element, which relies on the international nature of the judicial bodies admitting or not the information as evidence. Whereas the analysis above concentrated on procedural requirements referring to domestic experience, there might indeed be different combinations or hybrids between the adversarial and inquisitorial systems. Indeed, no single national system could offer a sufficient solution ${ }^{79}$. What becomes crucial at this point of our analysis is to now pay due attention to the international character of the proceedings before a judicial body operating outside the purely domestic context.

A seminal study on evidence in international proceedings concluded that "international tribunals would be seldom troubled with questions of reception or exclusion, based upon the intrinsic character of the evidence itself" 80 . According to M.O. Hudson, "No general rules have been developed to constitute an international law of evidence, and international tribunals are usually free from limitations of national tribunals in this regard" $"$. Apart from special provisions, international tribunals claim, and indeed exercise, complete freedom in the admission and evaluation of evidence in order to arrive at the moral conviction of

78 Erdemovic, Judgement, Separate and Dissenting Opinion of Judge Cassese, Erdemović (IT-96-22), AJ, 7 October 1997, § 2.

79 ACQUAVIVA, GUIDO. Written and oral evidence. In: CARTER, Linda; POCAR, Fausto (eds.). International Criminal procedure: The Interface of Civil Law and Common Law Legal Systems, Cheltenham: Edward Elgar 2013.

SANDIFER, Durward V. Evidence Before International Tribunals. Chicago: The Foundation Press, 1939, p. 119.Earlier in his treatise the mentioned author opines that "no rule of evidence thus finds more frequent statement in the cases than the one that international tribunals are not bound to adhere to strict rules of evidence." (at p. 9).

81 HUDSON, Manley O. International Tribunals. Past and Future. Washington: Carnegie Endowment for International Peace and Brookings Institution, 1944, p. 92. 
truth of the whole case ${ }^{82}$. A tendency in the practice of international tribunals is "to accept all possible means by which the disputed facts could be proved" 83 . Of course, one may be tempted to offer special treatment to newer international tribunals of a criminal character, to be distinguished from the traditional inter-state litigation ${ }^{84}$. In contrast to other international bodies, evidence plays a very prominent role in the decision-making by international criminal courts, as the latter are entrusted with determining the individual's criminal responsibility and not the liability of States. But also, international criminal tribunals suffer from difficulties in securing state cooperation and access to evidence.

Therefore, despite the apparent differences, a general conclusion may be drawn that international tribunals, including criminal courts and tribunals, have generally had the power to decide for themselves what is admissible as evidence and have indeed taken a liberal approach to the matter ${ }^{85}$. It may be even claimed that free evaluation of evidence should be considered a general principle of international law $^{86}$.

82 CHENG, Bin. General Principles of Law as Applied by International Courts and Tribunals. Cambridge: CUP, 2006, p. 307. See also BROWER, Charles N. The Anatomy of Fact-Finding before International Tribunals: An Analysis and a Proposal Concerning the Evaluation of Evidence. In: LILLICH, Richard (ed.). Fact-Finding by International Tribunals. Ardsley-on-Hudson: Transnational Publishers, 1991, p. 148 ("By and large there are no rules of evidence applied in international proceedings that automatically would evaluate evidence for reliability and potentially exclude it. Usually anything offered is admitted. For obvious diplomatic reasons international tribunals are especially reluctant to spurn anything proffered by a sovereign").

83 KAZAZI, Mojtaba. Burden of Proof and Related Issues: A Study on Evidence Before International Tribunals. The Hague: Kluwer Law International, 1996, p. 186.

84 Due to differing functions, parties, and procedures of different tribunals, a general analysis of evidentiary practice is rendered difficult, but it is possible to identify some similar approaches to the international law of evidence - see RIDELL, Anna.Evidence, Fact-Finding, and Experts. In: ROMANO, Cesare P.R.; ALTER, Karin; SHANY, Yuval (eds.). The Oxford Handbook of International Adjudication. Oxford: OUP, 2013, p. 850, 868. AMERASINGHE, Chittharanjan F. Evidence in International Litigation. Leiden, Boston: Martinus Nijhoff Publishers, 2005, p. 164. KLAMBERG, Mark. Evidence in International Criminal Trials. Leiden: Brill, 2013, p. 418. 


\section{Concluding ReMARKS}

The foregoing study has alluded to the importance of admissibility of evidence in the context of international criminal proceedings. Despite some problems presented above, the judicial practice has generally struck the necessary balance between ensuring the fair trial requirements and managing the judicial proceedings in a sometime stormy navigation between the inquisitorial and adversarial elements, while maintaining the character of an international judicial body.

The attention paid to admissibility of evidence distinguishes international criminal justice from traditional international courts and tribunals with their natural inclination to flexible procedural and evidentiary frameworks.

All in all, the general position of international criminal justice towards admissibility of evidence proves similar to the general flexibility of the proceedings and struggle to establish truth by the majority of (if not all) international courts and tribunals. The attempt to "install a flexible law of the evidence in a predominantly adversarial trial under the current demands of international criminal justice" may be considered "at the very least a highly dubious undertaking" ${ }^{87}$ but it should be borne in mind that any such hybridization of the procedure has been possible and effective. It has indeed been successfully taking place for decades now, due to the utmost care exercised by judges, even if their direct influence on procedural law, and evidentiary issues in particular, has been considerably diminished by the Rome Statute.

\section{References}

ACQUAVIVA, GUIDO. Written and oral evidence. In: CARTER, Linda; POCAR, Fausto (eds.). International Criminal procedure: The Interface of Civil Law and Common Law Legal Systems, Cheltenham: Edward Elgar 2013.

AMBOS, Kai. International Criminal Procedure: "Adversarial", "Inquisitorial” or Mixed? In: BOHLANDER Michael (ed.). International Criminal Justice: A Critical Analysis of Institutions and Procedures, London: Cameron May, 2007.

87 ZAHAR Alexander; SLUITER, Goran. International Criminal Law: A Critical Introduction. Oxford: OUP, 2008, p. 394. 
AMBOS, Kai. Treatise on International Criminal Law: Volume III: International Criminal Procedure. Oxford: OUP, 2016. https://doi.org/10.1093/ law/9780199665617.001.0001

AMERASINGHE, Chittharanjan F. Evidence in International Litigation. Leiden, Boston: Martinus Nijhoff Publishers, 2005.

BIBAS, Stephanos; BURKE-WHITE, William W. International Idealism Meets Domestic-Criminal-Procedure Realism. Duke Law Journal, Vol. 59(4), 2010.

BITTI, Gilbert. Article 64. In: TRIFFTERER, Otto; AMBOS, Kai (eds.). The Rome Statute of the International Criminal Court, Third Edition. Oxford: Hart Publishing, 2016. https://doi.org/10.5771/9783845263571-1589

BOAS, Gideon. Admissibility of Evidence Under the Rules of Procedure and Evidence of the ICTY: Development of the "Flexibility Principle”. In: MAY, Richard et al. (eds.), Essays on ICTY Procedure and Evidence in Honour of Gabrielle Kirk McDonald. Leiden: Brill, 2001.

BOAS, Gideon; BISCHOFF, James L.; REID Natalie L.; TAYLOR III, B. Don. International Criminal Law Practitioner Library: International Criminal Procedure, Volume 3, Cambridge: CUP 2011. https://doi.org/10.1017/CBO9780511760563.010

BOISTER, Neil; CRYER, Robert (eds.). Documents on the Tokyo International Military Tribunal: Charter, Indictment and Judgments. Oxford: OUP 2008.

BRADY, Helen. The System of Evidence in the Statute of the International Criminal Court. In: LATTANZI, Flavia; SCHABAS, William A. (eds.). Essays on the Rome Statute of the International Criminal Court. Volume 1, Il Sirente, 1999.

BROWER, Charles N. The Anatomy of Fact-Finding before International Tribunals: An Analysis and a Proposal Concerning the Evaluation of Evidence. In: LILLICH, Richard (ed.). Fact-Finding by International Tribunals. Ardsley-on-Hudson: Transnational Publishers, 1991.

CASSESE, Antonio. The Statute of the International Criminal Court: Some Preliminary Reflections. European Journal of International Law, Vol. 10, 1999. https:// doi.org/10.1093/ejil/10.1.144

COGAN, Jacob Katz. The Problem of Obtaining Evidence for International Criminal Courts, Human Rights Quarterly, Vol. 22, no. 2, 2000. https://doi.org/10.1353/ hrq.2000.0021

CHENG, Bin. General Principles of Law as Applied by International Courts and Tribunals. Cambridge: CUP, 2006. 
COMBS, Nancy. Evidence. In: SCHABAS, William A.; BERNAZ, Nadia (eds.). Routledge Handbook of International Criminal Law. New York: Routledge, 2011. https://doi.org/10.4324/9780203836897.ch20

COMBS, Nancy Amoury. Grave crimes and weak evidence: A fact-finding evolution in international criminal law, Harvard International Law Journal, Vol. 58, 2017.

DRUMBL, Mark A. Atrocity, Punishment, and International Law, Cambridge: CUP 2007. https://doi.org/10.1017/cbo9780511611100

FALLAH, Sara Mansour. The Admissibility of Unlawfully Obtained Evidence before International Courts and Tribunals, The Law \& Practice of International Courts and Tribunals, Vol. 19, 2020, p. 148. https://doi.org/10.1163/15718034-12341420

FLETCHER, George P. The Interplay of International Criminal Law and Other Bodies of Law, The Influence of the Common Law and Civil Law Traditions on International Criminal Law. In: CASSESE, Antonio (ed.). The Oxford Companion to International Criminal Justice. Oxford: OUP, 2009.

GALLMETZER, Reinhold. The Trial Chamber's Discretionary Power To Devise The Proceedings Before It And Its Exercise In The Trial Of Thomas Lubanga Dyilo. In: STAHN, Carsten; SLUITER, Goran (eds.). The Emerging Practice of the International Criminal Court. Leiden: Brill, 2009. https://doi.org/10.1163/ ej.9789004166554.i-774.144

GOODHART, Arthur L. The Legality of the Nuremberg Trials. In: METTRAUX, Guénaël. Perspectives on the Nuremberg Trial. Oxford: OUP 2008.

GOSNELL, Christopher. Admissibility of Evidence. In: KHAN, Karim A.A.; BUISMAN, Caroline; GOSNELL, Christopher (eds.). Principles of Evidence in International Criminal Justice, Oxford: OUP, 2010.

HUDSON, Manley O. International Tribunals. Past and Future. Washington: Carnegie Endowment for International Peace and Brookings Institution, 1944.

HUNT, David. The International Criminal. Court. High Hopes, 'Creative Ambiguity' and an Unfortunate Mistrust in International Judges. Journal of International Criminal Justice, Vol. 2, 2004. https://doi.org/10.1093/jicj/2.1.56

JASIŃSKI, Wojciech. Admissibility of Illegally Obtained Evidence in Proceedings before International Criminal Courts. In: KRZAN, Bartłomiej (ed.). Prosecuting International Crimes: A Multidisciplinary Approach. Leiden-Boston: Brill, 2016. https://doi.org/10.1163/9789004323667_011 
KAZAZI, Mojtaba. Burden of Proof and Related Issues: A Study on Evidence Before International Tribunals. The Hague: Kluwer Law International, 1996.

KLAMBERG, Mark. Evidence in International Criminal Trials. Leiden: Brill, 2013. https://doi.org/10.1163/9789004236523

KRESS, Claus. The Procedural Law of the International Criminal Court in Outline: Anatomy of a Unique Compromise. Journal of International Criminal Justice, Vol. 1, 2003. https://doi.org/10.1093/jicj/1.3.603

KWON, O-Gon. The Challenge of An International Criminal Trial as Seen from the Bench. Journal of International Criminal Justice, Vol. 5, 2007. https://doi. org/10.1093/jicj/mql094

MACDONALD, Gabrielle Kirk. Trial Procedures and Practices, in MACDONALD, Gabrielle Kirk; SWAAK-GOLDMAN Olivia. Substantive and Procedural Aspects of International Criminal Law: The Experience of International and National Courts. Vol. 1, The Hague: Kluwer Law International, 2000.

MAY, Richard; WIERDA, Marieke. International Criminal Evidence, Ardsley, NY: Transnational Publishers, 2002.

MAY, Richard; WIERDA, Marieke. Trends in International Criminal Evidence: Nuremberg, Tokyo, The Hague, and Arusha, Columbia Journal of Transnational Law, Vol. 37, 1999.

MURPHY, Peter. Evidence, Proof, and Facts - A Book of Sources. Oxford: OUP, 2003.

MURPHY, Peter. Excluding justice or facilitating justice? International criminal law would benefit from rules of evidence. International Journal Evidence and Proof, Vol. 12, 2008.

MURPHY, Peter. No Free Lunch, No Free Proof: The Indiscriminate Admission of Evidence is a Serious Flaw in International Criminal Trials. Journal of International Criminal Justice, Vol. 8, 2010. https://doi.org/10.1093/jicj/mqq029

ORIE, Alphons. Accusatorial versus Inquisitorial Approach in International Criminal Proceedings. In: CASSESE, Antonio; GAETA, Paola; JONES, John R.W.D. (eds.). The Rome Statute of the International Criminal Court: A Commentary. Oxford: OUP, 2002.

OSIEL, Mark. Making Sense of Mass Atrocity, Cambridge: CUP, 2009. https://doi. org/10.1017/CBO9780511596575 
PIRAGOFF, Donald K. Evidence. In LEE, R.S. (ed.), The International Criminal Court-Elements of Crimes and Rules of Procedure and Evidence. Ardsley: Transnational Publishers, 2001.

PIRAGOFF, Donald K.; CLARKE, Paula. Article 69. In: TRIFFTERER, Otto; AMBOS, Kai (eds.). The Rome Statute of the International Criminal Court, Third Edition. Oxford: Hart Publishing, 2016. https://doi.org/10.5771/9783845263571-1713

RIDELL, Anna.Evidence, Fact-Finding, and Experts. In: ROMANO, Cesare P.R.; ALTER, Karin; SHANY, Yuval (eds.). The Oxford Handbook of International Adjudication. Oxford: OUP, 2013. https://doi.org/10.1093/law/9780199660681.003.0039

SANDIFER, Durward V. Evidence Before International Tribunals. Chicago: The Foundation Press, 1939.

SCHABAS, William A. The International Criminal Court: A Commentary on the Rome Statute, Second Edition. Oxford: OUP, 2016. https://doi. org/10.5040/9781849469982.part-006

SCHUON, Christine. The Appeals Decision in the ICC's Jean-Pierre Bemba Gombo Case on the Trial Chamber's 'Decision on the Admission into Evidence of Materials Contained in the Prosecution's List of Evidence'. Leiden Journal of International Law, Vol. 25, 2012. https://doi.org/10.1017/s0922156512000180

SWART, Bert. International criminal courts and the admissibility of evidence. In: THAKUR, R. Chandra; MALCONTENT, Peter (eds.). From Sovereign Impunity to International Accountability: The Search for Justice in a World of States. Tokyo: United Nations University Press, 2004.

TAYLOR, Telford. The Anatomy of the Nuremberg Trials: A Personal Memoir. London: Bloomsbury 1993.

WALLACH, Evan J. The Procedural and Evidentiary Rules of the Post-World War II Crimes Trials: Did They Provide an Outline for International Legal Procedure. Columbia Journal of Transnational Law Vol. 37, 1999.

ZAHAR Alexander; SLUITER, Goran. International Criminal Law: A Critical Introduction. Oxford: OUP, 2008. 


\section{Additional information and author's declarations (scientific integrity)}

Acknowledgement: I extend my gratitude to the Editors of Revista Brasileira de Direito Processual Penal as well as the two anonymous reviewers for their inspiring and helpful comments and insights.

Conflict of interest declaration: the author confirms that there are no conflicts of interest in conducting this research and writing this article.

Declaration of authorship: all and only researchers who comply the authorship requirements of this article are listed as authors; all coauthors are fully responsible for this work in its entirety.

Declaration of originality: the author assures that the text here published has not been previously published in any other resource and that future republication will only take place with the express indication of the reference of this original publication; he also attests that there is no third party plagiarism or self-plagiarism.

Editorial process transparency

(http://www.ibraspp.com.br/revista/index.php/RBDPP/about/editorialPolicies)

- Submission date: 15/12/2020

Editorial team responsible

- Preliminary control and similarity verification:

- Editor-in-chief: 1 (VGV) 04/01/2021

- Review 1: 09/01/2021

- Associated-editor: 1 (KK)

- Review 2: 17/01/2021

- Reviewers: 3

- Review 3: 18/01/2021

- Editorial decision 1: 02/02/2021

- Correction round return: 17/02/2021

- Final editorial decision: 18/02/2021 


\section{COMO CITAR ESTE ARTIGO (ABNT):}

KRZAN, Bartłomiej. Admissibility of evidence and international criminal justice. Revista Brasileira de Direito Processual Penal, Porto Alegre, vol. 7, n. 1, p. 161-188, jan./abr. 2021. https://doi.org/10.22197/rbdpp.v7i1.492

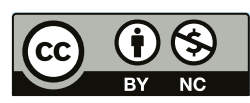

Esta obra está licenciada com uma Licença Creative Commons Atribuição-NãoComercial 4.0 Internacional. 